\title{
Pengetahuan dan Perilaku Mahasiswa Terkait Computer Vision Syndrome (CVS) serta Penggunaan dan Penyimpanan Obat Tetes Mata sebagai Penanganannya
}

\author{
Ariffio Dava Prihandoyo, Gede Parisudha Tegeh Putra, Lavinia Gunawan, Nadia Natsya Al Khalifi, Nurul A'ilda \\ Ma'rufah, Putu Anindita Saraswati, Rifqi Anindita Karunia, Romandani Puspita, Selvia Febriana Astuti, Siti Khotijah, \\ Mufarrihah* \\ Departemen Farmasi Komunitas, Fakultas Farmasi, Universitas Airlangga \\ Gedung Nanizar Zaman Joenoes Kampus C, Jl. Ir. Soekarno, Surabaya 60115, Indonesia \\ *E-mail: mufarrihah@ff.unair.ac.id
}

\begin{abstract}
ABSTRAK
Adanya COVID-19 di Indonesia menyebabkan pemerintah menetapkan kebijakan untuk melakukan kegiatan pembelajaran jarak jauh (daring). Kondisi ini dapat memicu masalah pada mata dan meningkatkan risiko terkena Computer Vision Syndrome (CVS). Penelitian ini dilakukan untuk mengidentifikasi pengetahuan dan perilaku mahasiswa mengenai CVS serta mengidentifikasi profil pengetahuan mahasiswa mengenai penyimpanan dan penggunaan obat tetes mata terkait CVS. Penelitian ini merupakan penelitian deskriptif cross-sectional. Metode pengambilan data melalui survei online. Subjek penelitian adalah mahasiswa yang berkuliah di perguruan tinggi di Kota Surabaya yang sedang melakukan pembelajaran jarak jauh. Penentuan subjek penelitian menggunakan teknik purposive sampling. Kuesioner berisikan pertanyaan tentang pengetahuan terkait CVS, perilaku terkait CVS, dan pengetahuan mengenai penggunaan obat tetes mata. Didapatkan total 133 responden dengan perolehan 100 responden $(75,19 \%)$ memiliki pengetahuan mengenai CVS yang cukup baik, 69 responden $(51,88 \%)$ memiliki perilaku yang menyebabkan risiko tinggi terkena CVS dan 71 responden $(53,36 \%)$ memiliki pengetahuan yang cukup baik dalam penyimpanan dan penggunaan obat tetes mata terkait CVS. Berdasarkan hasil survei dapat disimpulkan sebagian besar responden memiliki pengetahuan yang cukup baik terkait CVS serta penyimpanan dan penggunaan obat tetes mata namun masih banyak responden memiliki perilaku yang menyebabkan risiko tinggi terkena CVS.
\end{abstract}

Kata kunci: Computer Vision Syndrome, gangguan mata, obat tetes mata.

\begin{abstract}
The number of positive cases of COVID-19 spread in Indonesia continues to increase so that the government sets policies for conducting distance learning activities (online). This condition can trigger problems in the eyes and increase the risk of developing Computer Vision Syndrome (CVS). This research was conducted to identify students' knowledge and behaviour regarding CVS and identify student knowledge profiles about the use and storage of CVS-related eye medications. This type of research was a cross-sectional descriptive study conducted on 133 respondents with data collection method through online surveys. The subject of the research was students who studying at a college in Surabaya who were doing online learning. Determination of research subjects using accidental sampling techniques. From the survey results, $100(75.19 \%)$ respondents had good knowledge about CVS, 69 (51.88\%) respondents' behaviors led to a high risk of exposure to CVS and $71(53.36 \%)$ respondents had a good knowledge in the use and storage of CVS-related eye drops. Based on survey results can be concluded most respondents have a good knowledge of CVS as well as the use and storage of eye medications but still many respondents have behaviours that cause a high risk of developing CVS.
\end{abstract}

Keyword: Computer Vision Syndrome, Eye Disorders, Eye Drops 


\section{PENDAHULUAN}

Jumlah kasus positif penyebaran COVID-19 di Indonesia terus mengalami peningkatan. Dalam Surat Edaran Menteri Sosial Republik Indonesia No 2 Tahun 2020, pemerintah memberikan regulasi terkait Aparatur Sipil Negara (ASN) untuk bekerja dari rumah. Selain pekerja, mahasiswa pun diharuskan melakukan kegiatan pembelajaran di rumah yang diatur dalam Surat Edaran Direktur Jenderal Pendidikan Tinggi Nomor 1 tahun 2020. Berdasarkan survei dari Property \& Consumer Good Industry at MarkPlus, terhadap 124 responden dengan 58,1\% berasal dari Jabodetabek, sebanyak 31,4\% masyarakat mengalami kenaikan penggunaan panggilan video (videocall) selama masa pandemi. Video conference daring naik $33,5 \%$, sama halnya online video atau movie streaming mengalami kenaikan dari 76,6\% menjadi 85,5\% (Salsabila, 2020). Kondisi seperti ini dapat memicu masalah pada mata yang meningkatkan risiko mengalami Computer Visual Syndrome (CVS).

American Optometric Association menyebutkan, CVS adalah gangguan penglihatan akibat penggunaan komputer dengan durasi yang lama. Gangguan penglihatan ini disebabkan oleh cahaya terang atau sinar biru dari layar komputer yang masuk ke mata karena harus terus menerus memfokuskan penglihatan saat sedang membaca atau melihat sesuatu di monitor. Keluhan yang dialami penderita CVS antara lain ketegangan pada mata, sakit kepala, penglihatan kabur, mata kering, serta nyeri leher dan bahu (AOA, 2020). Prevalensi CVS pada pengguna komputer mencapai 64-90\%. Sebanyak lebih dari $80 \%$ mahasiswa teknik dan lebih dari $75 \%$ mahasiswa kedokteran mengalami sindroma mata ini (Amalia, 2018).

Cara mengatasi CVS dapat dilakukan dengan intervensi non-farmakologis atau farmakologis. Intervensi non-farmakologis atau dapat disebut dengan intervensi kebiasaan sehari-hari dengan tidak menggunakan obat-obatan. Beberapa kebiasaan yang harus dilakukan untuk menangani sindrom ini adalah menjaga posisi mata 20 - 28 inci dari komputer, mengurangi cahaya yang berasal dari komputer menggunakan teknologi layar antiglare, mengatur posisi duduk dan mengetik yang tepat, melakukan istirahat mata selama 15-20 menit setelah menatap layar selama 2 jam, serta sering mengedipkan mata agar mata tetap lembab (AOA, 2020). Sedangkan, intervensi farmakologis dapat dilakukan dengan pemberian obat-obatan untuk mengurangi gejala yang muncul. Beberapa studi terkait pengobatan CVS telah dilakukan dan didapatkan beberapa pilihan terapi, yaitu air mata buatan (artificial tears), obat tetes mata herbal, obat golongan analgesik, dan steroid (Akinbinu dan Mashalla, 2014).
Terdapat dua jenis obat tetes mata dalam penggunaannya yaitu obat tetes mata single dose dan multiple dose yang perlu diketahui karakternya masing-masing. Namun, penggunaan dan penyimpanan produk obat tetes mata masih belum diketahui oleh masyarakat dan mahasiswa (Julianto et al., 2015). Kurangnya kesadaran akan pentingnya cara penggunaan dan penyimpanan obat tetes mata akan mengakibatkan kerusakan yang lebih buruk (Laila et al., 2019). Oleh karena itu dilakukan survei kepada mahasiswa yang berkuliah di Surabaya untuk mengetahui perilaku, pengetahuan terkait CVS dan penggunaan serta penyimpanan obat tetes mata.

\section{METODE PENELITIAN}

Penelitian ini termasuk dalam jenis penelitian deskriptif dengan pendekatan cross sectional. Subjek penelitian merupakan mahasiswa perguruan tinggi di Surabaya yang melakukan pembelajaran daring.

Penentuan subjek penelitian menggunakan teknik sampling metode non-random sampling dengan purposive sampling. Pengambilan dilakukan pada Oktober 2020. Subjek dipilih yang sesuai dengan kriteria inklusi yaitu mahasiswa yang berkuliah di perguruan tinggi di Surabaya dan melaksanakan pembelajaran daring. Kriteria ekslusi penelitian ini adalah mahasiswa Fakultas Farmasi Universitas Airlangga dan mahasiswa yang sedang melakukan cuti semester.

Subjek penelitian kemudian diberikan kuesioner dalam bentuk Google Form. Google Form sebagai media atau instrumen memuat 28 pertanyaan terkait dengan perilaku CVS, pengetahuan CVS serta penggunaan dan penyimpanan obat tetes mata. Data yang diperoleh kemudian dilakukan scoring untuk mendapatkan hasil tersebut. Data yang diperoleh kemudian dianalisis secara deskriptif menggunakan Microsoft Excel.

\section{HASIL DAN PEMBAHASAN}

Berdasarkan hasil survei yang dilakukan pada bulan Oktober 2020 terhadap mahasiswa perguruan tinggi di Surabaya, diperoleh sebanyak 133 responden yang memenuhi kriteria inklusi. Pada data demografi seperti yang terlihat pada Tabel 1, jumlah responden berjenis kelamin perempuan dan laki-laki hampir sama. Domisili responden pada saat melakukan perkuliahan daring bervariasi dari Sumatera, Jawa, Bali, NTT, NTB, hingga Sulawesi namun mayoritas berdomisili di Provinsi Jawa Timur.

Pada Tabel 1 menunjukkan mayoritas responden merupakan mahasiswa yang sedang menempuh semester 7, paling banyak berasal dari Universitas Airlangga diikuti Institut Teknologi Sepuluh November dengan waktu menatap layar lebih dari 8 jam dalam sehari. 
Tabel 1. Gambaran Demografi Responden

\begin{tabular}{|c|c|c|}
\hline \multicolumn{2}{|c|}{ 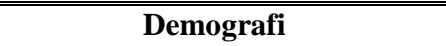 } & n(\%) \\
\hline \multirow{2}{*}{$\begin{array}{c}\text { Jenis } \\
\text { Kelamin }\end{array}$} & Perempuan & $68(51,13 \%)$ \\
\hline & Laki-laki & $65(48,87 \%)$ \\
\hline \multirow{12}{*}{$\begin{array}{c}\text { Perguruan } \\
\text { Tinggi }\end{array}$} & UNAIR & $69(51,88 \%)$ \\
\hline & ITS & $40(30,08 \%)$ \\
\hline & UPN JATIM & $6(4,51 \%)$ \\
\hline & ITATS & $4(3,01 \%)$ \\
\hline & UBAYA & $3(2,26 \%)$ \\
\hline & UINSA & $2(1,50 \%)$ \\
\hline & UNESA & $2(1,50 \%)$ \\
\hline & PPNS & $2(1,50 \%)$ \\
\hline & PENS & $2(1,50 \%)$ \\
\hline & UHT & $1(0,75 \%)$ \\
\hline & UKP & $1(0,75 \%)$ \\
\hline & UKDC & $1(0,75 \%)$ \\
\hline \multirow{5}{*}{ Semester } & 7 & $83(62,41 \%)$ \\
\hline & 1 & $22(16,54 \%)$ \\
\hline & 5 & $12(9,02 \%)$ \\
\hline & 3 & $11(8,27 \%)$ \\
\hline & 9 & $5(3,76 \%)$ \\
\hline \multirow{4}{*}{$\begin{array}{l}\text { Waktu } \\
\text { Menatap } \\
\text { Layar }\end{array}$} & Lebih dari 8 jam & $84(63,16 \%)$ \\
\hline & $4-8$ jam & $49(36,84 \%)$ \\
\hline & Lainnya & $0(0 \%)$ \\
\hline & Total & $133(100 \%)$ \\
\hline
\end{tabular}

Berdasarkan data survei yang diperoleh pada Tabel 2, sebagian besar responden memperoleh skor 68 dengan kategori cukup baik untuk aspek pengetahuan. Terkait aspek perilaku mengenai CVS diperoleh hasil 5-8 yang menunjukkan bahwa responden memiliki risiko tinggi mengalami CVS.
Pada aspek penggunaan dan penyimpanan obat tetes mata didapat skor 5-6 yang termasuk kategori cukup baik.

Tabel 2. Penilaian Pengetahuan CVS, Perilaku CVS dan Penggunaan serta Penyimanan Obat Tetes Mata

\begin{tabular}{|c|c|c|c|}
\hline $\begin{array}{c}\text { Aspek } \\
\text { Penilaian }\end{array}$ & Skor & n $(\%)$ & Kategori \\
\hline \multirow{3}{*}{$\begin{array}{c}\text { Pengeta- } \\
\text { huan } \\
\text { CVS }\end{array}$} & $\begin{array}{c}<60 \% \\
\text { (nilai 1-5) }\end{array}$ & $\begin{array}{c}18 \\
(13.53 \%)\end{array}$ & $\begin{array}{c}\text { Kurang } \\
\text { baik }\end{array}$ \\
\hline & $\begin{array}{c}60-80 \% \\
\text { (nilai 6-8) }\end{array}$ & $\begin{array}{c}100 \\
(75,19 \%) \\
\end{array}$ & $\begin{array}{l}\text { Cukup } \\
\text { baik }\end{array}$ \\
\hline & $\begin{array}{c}>80 \% \\
\text { (nilai 9-10) }\end{array}$ & $\begin{array}{c}15 \\
(11.28 \%)\end{array}$ & Baik \\
\hline \multirow{2}{*}{$\begin{array}{l}\text { Perilaku } \\
\text { CVS }\end{array}$} & $\begin{array}{c}<50 \% \\
\text { (nilai 1-4) } \\
\end{array}$ & $\begin{array}{c}64 \\
(48.12 \%) \\
\end{array}$ & $\begin{array}{l}\text { Risiko } \\
\text { rendah }\end{array}$ \\
\hline & $\begin{array}{c}>50 \% \\
\text { (niai 5-8) }\end{array}$ & $\begin{array}{c}69 \\
(51.88 \%) \\
\end{array}$ & $\begin{array}{l}\text { Risiko } \\
\text { tinggi }\end{array}$ \\
\hline \multirow{3}{*}{$\begin{array}{c}\text { Pengeta- } \\
\text { huan } \\
\text { dagusibu } \\
\text { obat mata }\end{array}$} & $\begin{array}{c}<60 \% \\
\text { (nilai 1-4) }\end{array}$ & $\begin{array}{c}19 \\
(14.28 \%)\end{array}$ & $\begin{array}{c}\text { Kurang } \\
\text { baik }\end{array}$ \\
\hline & $\begin{array}{c}60-80 \% \\
\text { (nilai 5-6) }\end{array}$ & $\begin{array}{c}71 \\
(53.38 \%) \\
\end{array}$ & $\begin{array}{c}\text { Cukup } \\
\text { baik }\end{array}$ \\
\hline & $\begin{array}{c}>80 \% \\
\text { (nilai 7-8) }\end{array}$ & $\begin{array}{c}43 \\
(32.33 \%)\end{array}$ & baik \\
\hline
\end{tabular}

Berdasarkan data Tabel 3, mayoritas responden telah menjawab benar pada pertanyaan yang diajukan. Hal tersebut menunjukkan bahwa sebagian besar responden telah mengetahui gejala serta penanganan non-farmakologis CVS. Namun, pada pertanyaan nomor enam dan sembilan hanya terjawab benar sekitar 50-60\% responden serta lebih dari 70\% responden menjawab salah pada pertanyaan nomor satu dan pertanyaan nomor sepuluh, sehingga dapat diketahui bahwa responden memiliki pengetahuan yang kurang terkait definisi dan terapi farmakologis CVS.

Tabel 3. Profil Pertanyaan yang Dijawab oleh Responden.

\section{Pertanyaan}

Jawaban Benar n(\%)

Computer Vision Syndrome (CVS) merupakan gang-guan mata akibat terlalu lama menatap layar komputer/ laptop yag biasanya ditandani dengan keluarnya cairan berwarna kekuningan dari mata.

$35(26,32 \%)$

Sakit kepala dan leher merupakan gejala CVS.

Bekerja di depan komputer/ laptop dapat dilakukan secara terus-menerus dalam waktu lebih dari 4 jam.

Terlalu intens dalam menatap layar komputer menyebabkan mata tidak nyaman, perih

dan gatal.

Pengaturan kontras layar komputer/ laptop yang baik adalah mengatur layer dengan kontras yang tinggi.

$116(87,21 \%)$

$105(78,95 \%)$

$130(97,74 \%)$

$117(87,97 \%)$

Jarak yang tepat untuk menatap layar komputer/ laptop adalah $20 \mathrm{~cm}$.

$76(57,14 \%)$

Orang yang memakai kacamata (minus, plus atau lensa ganda) memiliki kecenderungan untuk mengalami gangguan lebih parah akibat menatap layar komputer/ laptop yang terlalu lama.

\begin{tabular}{ll}
\hline Mengalihkan pandangan dari layar secara berkala setiap 20 menit akan mencegah CVS. & $126(94,74 \%)$ \\
\hline Air mata buatan adalah produk yang digunakan untuk mengatasi CVS. & $79(59,40 \%)$ \\
\hline Mengonsumsi vitamin A dapat menyembuhkan CVS. & $27(20,30 \%)$ \\
\hline \hline
\end{tabular}


Gejala mata kering pada CVS dapat disebabkan karena produksi air mata yang kurang. Terapi yang dilakukan terutama fokus untuk mempertahankan atau meningkatkan produksi air mata, antara lain berkedip secara berkala, konsumsi suplemen yang mengandung asam lemak esensial, rehidrasi cairan tubuh dengan minum air yang cukup, serta pemberian air mata buatan (artificial tears) pada kasus mata kering sedang (AOA, 2017). Akinbinu dan Mashalla (2014) menyebutkan bahwa intervensi farmakologis untuk CVS dapat berupa pemberian obat tetes mata herbal, obat tetes mata golongan analgesik, dan steroid.

Tabel 4. Profil Perilaku Responden Terkait Risiko CVS

\begin{tabular}{lc}
\multicolumn{1}{c}{ Pernyatan } & $\mathbf{n}(\%)$ \\
\hline $\begin{array}{l}\text { Menatap layar/komputer lebih dari } 4 \\
\text { jam per hari }\end{array}$ & $122(97,73 \%)$ \\
\hline $\begin{array}{l}\text { Bekerja di depan layar } \\
\text { komputer/laptop/HP dengan kondisi } \\
\text { ruangan yang gelap }\end{array}$ & $39(29,32 \%)$ \\
\hline $\begin{array}{l}\text { Mengatur kontras layar } \\
\text { komputer/laptop/HP hingga } \\
\text { maksimal }\end{array}$ & $35(26,32 \%)$ \\
\hline $\begin{array}{l}\text { Tidak beristirahat secara berkala saat } \\
\text { bekerja di depan layar } \\
\text { laptop/komputer/HP }\end{array}$ & $31(23,31 \%)$ \\
\hline $\begin{array}{l}\text { Mengisi waktu istirahat dengan } \\
\text { menggunakan HP/gadget lainnya }\end{array}$ & $106(79,70 \%)$ \\
\hline $\begin{array}{l}\text { Mengalami mata lelah, kering, atau } \\
\text { pandangan kabur akibat menatap } \\
\text { layar komputer/laptop/HP }\end{array}$ & $90(67,67 \%)$ \\
\hline $\begin{array}{l}\text { Tidak menggunakan kacamata anti } \\
\text { radiasi (blueray) saat bekerja di } \\
\text { depan komputer/laptop/HP }\end{array}$ & $94(70,68 \%)$ \\
\hline $\begin{array}{l}\text { Tidak menggunakan obat tetes mata } \\
\text { untuk mengatasi gangguan mata } \\
\text { akibat menatap layar } \\
\text { komputer/laptop/HP }\end{array}$ & $110(82,71 \%)$ \\
\hline \hline
\end{tabular}

Berdasarkan penelitian yang dilakukan Azkadina, dkk., 2012 dan Kurmasela, dkk., 2013, disebutkan bahwa menatap layar komputer/laptop/HP selama lebih dari 4 jam akan meningkatkan resiko menderita CVS. Lama waktu mulai merasakan keluhan penglihatan akibat menatap layar berhubungan signifikan dengan keluhan penglihatan mata terasa gatal, mata terasa kering, mata terasa nyeri, mata tegang atau lelah, mata berair, dan penglihatan kabur atau berbayang. Hal tersebut sesuai dengan penelitian ini yang tertera pada Tabel 4 menunjukkan sebanyak $97,73 \%$ responden menatap layar komputer lebih dari 4 jam. Hal tersebut diperparah oleh perilaku responden yang beristirahat dengan bermain HP/gadget lainnya sebesar 79,70\%.

Dari perilaku tersebut tentunya diperlukan cara dalam mencegah CVS, salah satunya adalah dengan menggunakan kacamata antiradiasi (blueray). Berdasarkan hasil survei, sebanyak 70,68\% responden tidak menggunakan kacamata anti radiasi (blueray) dalam beraktivitas di depan layar komputer/laptop/HP. Selain itu, $82,71 \%$ responden tidak mengatasi gangguan mata yang dialami akibat menatap layar komputer/laptop/HP menggunakan obat tetes mata. Penggunaan obat tetes mata memberikan efek rehidrasi pada mata sehingga dapat digunakan untuk mengatasi CVS (AOA, 2017). Berdasarkan uraian di atas, sebagian besar responden memiliki perilaku yang meningkatkan risiko CVS.

Pada Tabel 5 ditunjukkan bahwa dari 133 responden, sebagian besar termasuk kategori cukup baik mengenai pengetahuan tentang obat tetes mata. Sedangkan pada Tabel 6, dapat dilihat bahwa pada pertanyaan nomor empat terdapat $94,70 \%$ responden yang menjawab benar paling banyak. Hal ini menunjukkan bahwa sebagian besar responden sudah mengetahui bahwa mereka harus mencuci tangan sebelum dan sesudah memakai obat tetes mata. Tujuh dari delapan pertanyaan yang diberikan terhadap responden, didapat persentase jawaban benar diatas $67 \%$, sehingga dapat disimpulkan bahwa mayoritas responden sudah memiliki pengetahuan yang baik tentang obat tetes mata.

Tabel 5. Pengetahuan Tentang Obat Tetes Mata

\begin{tabular}{ccc}
\hline Skor & $\begin{array}{c}\text { Jumlah } \\
\text { Responden } \\
\mathbf{n}(\%)\end{array}$ & Kategori \\
\hline $1-4$ & $19(14,29)$ & $\begin{array}{c}\text { Kurang } \\
(<60 \%)\end{array}$ \\
\hline$(12,5-50 \%)$ & $71(53,38)$ & $\begin{array}{c}\text { Cukup Baik } \\
(60-80 \%)\end{array}$ \\
\hline $5-6$ & $43(32,33)$ & Baik $(>80 \%)$ \\
\hline $7-8$ & & \\
\hline \hline
\end{tabular}


Tabel 6. Pertanyaan Pengetahuan Obat tetes mata

\begin{tabular}{lc}
\hline \multicolumn{1}{c}{ Pertanyaan } & $\begin{array}{c}\text { Jawaban benar } \\
\text { n }(\%)\end{array}$ \\
\hline $\begin{array}{l}\text { Kita boleh menggunakan obat tetes } \\
\text { mata milik orang lain dengan gejala }\end{array}$ & $90(67,67 \%)$ \\
yang sama & \\
\hline $\begin{array}{l}\text { Obat tetes mata yang telah dibuka, } \\
\text { hanya dapat digunakan dalam jangka } \\
\text { waktu 30 hari }\end{array}$ & $94(70,67 \%)$ \\
\hline $\begin{array}{l}\text { Obat tetes mata digunakan dengan } \\
\text { cara meneteskannya langsung pada } \\
\text { bola mata }\end{array}$ & $17(12,79 \%)$ \\
\hline $\begin{array}{l}\text { Sebelum dan sesudah menggunakan } \\
\text { obat tetes mata harus mencuci } \\
\text { tangan. }\end{array}$ & $126(94,70 \%)$ \\
\hline $\begin{array}{l}\text { Setelah meneteskan obat tetes mata } \\
\text { memejamkan mata sekitar 2-3 menit }\end{array}$ & $116(87,20 \%)$ \\
\hline $\begin{array}{l}\text { Untuk membersihkan ujung botol } \\
\text { tetes mata dapat dilakukan dengan } \\
\text { cara menyeka atau membilas ujung } \\
\text { botol tetes dengan tangan }\end{array}$ & $100(75,20 \%)$ \\
\hline $\begin{array}{l}\text { Obat tetes mata disimpan pada suhu } \\
\text { kamar 25 } 5^{\circ} \mathrm{C}\end{array}$ & $117(87,96 \%)$ \\
\hline $\begin{array}{l}\text { Obat tetes mata dimusnahkan dengan } \\
\text { cara mengeluarkan isinya dan } \\
\text { merusak kemasannya }\end{array}$ & $111(83,46 \%)$ \\
\hline \hline
\end{tabular}

Akan tetapi, pada pertanyaan nomor tiga hanya $12,79 \%$ responden yang menjawab benar, sehingga dapat dilihat mayoritas responden menjawab bahwa cara penggunaan obat tetes mata dapat langsung diteteskan pada bola mata. Hal ini menunjukkan kurangnya pengetahuan responden tentang cara menggunakan obat tetes mata yang benar. Penggunaan obat tetes mata yang benar yaitu pada kelopak mata bagian bawah karena pada bagian tersebut lebih membentuk kantung mata, sehingga saat diteteskan lebih mudah masuk ke mata (BPOM, 2018). Kurangnya pemahaman tentang penggunaan obat tetes mata ini dapat disebabkan karena tidak tersampaikannya informasi tentang penggunaan tetes mata yang benar. Pemberian informasi setelah pemberian obat diperlukan untuk mengubah persepsi yang kurang tepat mengenai penggunaan obat tetes mata.

\section{KESIMPULAN}

Berdasarkan hasil penelitian diketahui bahwa sebagian besar mahasiswa sudah memiliki pengetahuan yang cukup baik tentang Computer Vision Syndrome yang terlihat dari banyaknya pertanyaan yang dijawab benar oleh responden. Sedangkan terkait pengetahuan penyimpanan dan penggunaan obat tetes mata, sebagian besar dari responden telah memahami hal tersebut. Namun, perilaku yang ditunjukkan responden menyebabkan resiko tinggi terkena CVS.

\section{UCAPAN TERIMA KASIH}

Ucapan terima kasih diberikan kepada dosen pembimbing kelompok atas dukungan selama pembuatan ini melalui bimbingan, kritik, dan saran yang sangat membantu kami.

\section{DAFTAR PUSTAKA}

Amalia, H. (2018) 'Computer Vision Syndrome', Jurnal Biomedika dan Kesehatan, 1(2).

Akinbinu, T. R. and Mashalla, Y. J. (2014) 'Impact of computer technology on health: Computer Vision Syndrome (CVS)', Academic Journal, 5(3).

AOA. Computer Vision Syndrome. (2020). American Optomeric Association viewed 14 September 2020. https://www.aoa.org/healthy-eyes/eyeand-vision-conditions/computer-visionsyndrome?sso=y.

Azkadina, A., Julianti, H. and Pramono, D. (2012) 'Hubungan Antara Faktor Risiko Individual Dan Komputer Terhadap Kejadian Computer Vision Syndrome', Jurnal Kedokteran Diponegoro, 1(1), pp. 137662.

Juliyanto, T., Mayasari, B. W. C., Widianti, C., Abadi, F. S., Poniwati, K., Fitri, N. A., Sari, R. S., Fatmawati, R. L., Imawan, R., Anggraeni, S. R., \& Madina, U. (2015) 'Penggunaan dan penyimpanan sediaan topikal multidose untuk mata;. Jurnal Farmasi Komunitas, 2(2), pp.52-56.

Kementerian Pendidikan dan Kebudayaan RI (2020) Surat Edaran Direktur Jenderal Pendidikan Tinggi Republik Indonesia Nomor 1 Tahun 2020 tentang Pencegahan Penyebaran Corona Virus Disease ( Covid-19) di Perguruan Tinggi.

Kurmasela, G. P., Saerang, J. S. M. and Rares, L. (2013) 'Hubungan Waktu Penggunaan Laptop Dengan Keluhan Penglihatan Pada Mahasiswa Fakultas Kedokteran Universitas Sam Ratulangi', Jurnal e-Biomedik, 1(1). doi: 10.35790/ebm.1.1.2013.4361.

Laila, A. N. N. et al. (2019) 'Tingkat Pengetahuan Masyarakat Di Daerah Joyoboyo Tentang Penyakit Mata Dan Sediaan Obat tetes mata', Jurnal Farmasi Komunitas, 6(1), pp. 9. doi: 10.20473/jfk.v6i1.21822.

Menteri Sosial Republik Indonesia (2020) Surat Edaran no 2 tahun 2020'.

Pusat Informasi Obat Nasional, Badan Pengawas Obat dan Makanan Republik Indonesia (2015.) Petunjuk Praktis Penggunaan Obat 
viewed $26 \quad$ November 2020. http://pionas.pom.go.id/ioni/lampiran-6petunjuk-praktis-penggunaan-obat-yangbenar/petunjuk-praktis-penggunaan-obat Salsabila, D. A. (2020) Peningkatan Konsumsi Internet Saat Pandemi viewed 1 November 2020. http://www.forshei.org/2020/11/pandemicovid-19-telah-mengubah.html

Wimalasundera, S. (2006) 'Computer Vision Syndrome, Galle Medical Journal, 11(1), pp. 25-29 